\title{
Penggunaan Media Audio Visual dalam Meningkatkan Pemahaman Seni Tari pada Peserta Didik Kelas V SDN Ende 5 Kabupaten Ende
}

\author{
Antonia Y.W. Wea ${ }^{1 *}$, Maria Purnama Nduru ${ }^{2}$, Frumensius B. Dole ${ }^{3}$ \\ 1,2,3 Program Studi PGSD Universitas Flores Ende. \\ Jalan Samratulangi, Kelurahan Pupire, Ende, Flores, Indonesia \\ E-mail: antoniayosefaputri@gmail.com
}

\begin{abstract}
Info Artikel Abstract
Sejarah Artikel:

Diterima 13/02/2020

Direvisi 09/03/2020

Disetujui 17/03/2020

Keywords:

Audio Visual Media,

Understanding

Dance

The purpose of this research is to define the use of audio-visual media in improving dance understanding in students, to find out the understanding of dance after using audio-visual media. This type of research is a classroom action research (CAR). This research was conducted in a recurring cycle through four stages namely planning, implementing, observing, reflecting. This research was conducted at Ende 5 Elementary School in Ende Regency. The subjects in this study were grade $V$ students, amounting to 28 people. The collection methods used are interviews, observation, documenta tion, and test. Analysis of the data used in this study is a qualitative descriptive analysis of teacher observation, observation of student learning activities and student understanding of the results. Based on the results of the evaluation of the first cycle with a percentage of mastery comprehension of students $50 \%$ with an average of $72.53 \%$, the results of the evaluation of the second cycle with the percentage of completeness of students' understanding $82.14 \%$ with an average of $78.67 \%$ then the use of audio visual media can improve understanding dance with an increase of $6.14 \%$.
\end{abstract}

\begin{abstract}
Abstrak
Tujuan penelitian adalah untuk mendefenisikan penggunaan media audio visual dalam meningkatkan pemahaman seni tari pada peserta didik, untuk mengetahui pemahaman seni tari setelah menggunakan media audio visual. Jenis penelitian ini yang dilakukan adalah penelitian tindakan kelas (PTK). Penelitian ini lakukan secara siklus berulang melalui empat tahap yaitu perencanaan, pelaksanaan, pengamatan, refleksi. Penelitian ini dilaksanakan di SDN Ende 5 Kabupaten Ende. Subjek dalam penelitian ini adalah peserta didik kelas V yang berjumlah 28 orang. Metode pengumpulan yang digunakan adalah wawancara, observasi, dokumentasi, dan tes. Analisis data yang digunakan dalam penelitian ini adalah analisis deskriptif kualitatif berupa observasi guru, observasi aktivitas belajar peserta didik dan hasil pemahaman peserta didik. Berdasarkan hasil evaluasi siklus I dengan presentase ketuntasan pemahaman siswa 50\% dengan rata-rata $72,53 \%$, hasil evaluasi siklus II dengan presentase ketuntasan pemahaman siswa $82,14 \%$ dengan rata-rata $78,67 \%$ maka penggunaan media audio visual dapat meningkatkan pemahaman seni tari dengan peningkatan $6,14 \%$.
\end{abstract}

\footnotetext{
"Alamat korespondensi:

Program Studi Pendidikan Guru Sekolah Dasar

Fakultas Keguruan dan Ilmu Pendidikan Universitas Flores

Kampus III Universitas Flores, Jln. Samratulangi,

Kelurahan Paupire, Ende, NTT

E-mail: antoniayosefaputri@gmail.com

(C) 2020 Program Studi PGSD Universitas Flores Email: primagistrauniflor@gmail.com
} 
Antonia Y.W. Wea, Maria Purnama Nduru dan Frumensius B. Dole

Penggunaan Media Audio Visual dalam Meningkatkan Pemahaman Seni Tari pada Peserta Didik Kelas V SDN Ende 5 Kabupaten Ende

PRIMA MAGISTRA: Jurnal Ilmiah Kependidikan Nomor 1, Volume 1, April 2020, hal 77-84

\section{PENDAHULUAN}

Pendidikan pada dasarnya bermaksud membantu peserta didik untuk menumbuh kembangkan potensi kemanusiannya. Potensi kemanusiaan merupakan suatu benih kemungkinan untuk menjadi manusia. Pendidikan diartikan sebagai kegiatan pewarisan budaya dari satu generasi kegenerasi yang lain. Seperti bayi lahir yang sudah berada di dalam suatu lingkungan budaya tertentu. Di dalam lingkungan masyarakat dimana seorang bayi dilahirkan telah terdapat kebiasaan-kebiasaan tertentu, larangan-larangan dan anjuran, dan ajakan tertentu seperti yang dikehendaki oleh masyarakat. Hal-hal tersebut mengenai banyak hal seperti bahasa, cara menerima tamu, makanan, istirahat, bekerja, perkawinan, bercocok tanam dan seterusnya. Di sini tampak bahwa proses perwarisan budaya tidak semata-mata mengekalkan budaya secara estafet. Pendidikan justru mempunyai tugas menyimpulkan peserta didik untuk hari esok (Umar \& La, 2010:33).

Menurut Undang-Undang Sistem Pendidikan Nasional Nomor 20 tahun 2003 pendidikan diselenggarakan secara demokratis dan berkeadilan serta tidak diskriminatif dengan menjujung tinggi nilai hak asasi manusia, nilai keagamaan, nilai budaya dan kemajemukan bangsa dengan satu kesatuan yang sistemis dengan sistem terbuka dan multimakna. Selain itu, di dalam penyelenggaraan sistem pendidikan juga harus dalam satu proses pembudayaan dan pemberdayaan peserta didik yang berlangsung sepanjang hayat dengan memberikan keteladanan, membangun kemauan (niat, hasrat), dan mengembangkan kreatifitas peserta didik dalam proses pembelajaran melalui mengembangkan budaya membaca, menulis dan berhitung bagi segenap masyarakat dan memberdayakan semua komponen masyarakat melalui peran serta dalam penyelenggaraan dan pengendalian mutu layanan pendidikan. Kegiatan ektrakurikuler adalah kegiatan di luar jam pelajaran sekolah biasa, yang dilakukan di sekolah atau di luar sekolah dengan tujuan untuk memperluas pengetahuan siswa, mengenai hubungan antara mata pelajaran, menyalur bakat dan minat serta melengkapi pembinaan manusia seutuhnya. Kenyataan yang terjadi di SDN Ende 5 menunjukkan bahwa kebanyakan siswa SDN Ende 5 kurang aktif dalam menerima pelajaran seni tari kreasi ule lela nggewa, mereka lebih bersifat pasif untuk melakukan gerakan tarian yang diajaran guru. Dalam pembelajaran guru lebih cenderung menyajikan materi mengunakan metode ceramah dan kurang menggunakan alat peraga seni tari. Hal ini berdampak pada hasil belajar siswa yang kurang efektif. Dari hasil refleksi dan pengamatan terhadap masalah di atas, ditemukan beberapa faktor penyebab diantaranya, metode yang digunakan guru selama ini adalah metode ceramah, sehingga siswa cepat bosan dan siswa kurang aktif. Menyadari hal tersebut maka guru perlu mengubah cara membelajarkan siswa tentang seni tari kreasi Ule lela Nggewa dengan menggunakan media audio visual. Dari permasalahan di atas maka peneliti mengambil judul" Penggunaan media audio visual dalam meningkatkan pemahaman seni tari pada peserta didik kelas V SDN Ende 5 Kabupaten Ende".

\section{METODE PENELITIAN}

Jenis penelitian yang digunakan dalam penelitian ini adalah penelitian tindakan kelas. Menurut Mulyasa (2012:11) Penelitian tindakan kelas adalah suatu upaya untuk mencermati kegiatan belajar sekelompok peserta didik dengan memberikan sebuah tindakan (treatment) yang sengaja dimunculkan. Menurut Ningrum (2014) penelitian tindakan kelas adalah sebagai bentuk penelitian reflektif yang dilakukan oleh guru sendiri yang hasilnya dapat dimanfaatkan sebagai alat untuk pengembangan kurikulum, pengembangan sekolah, pengembangan keterampilan mengajar, dan sebagainya.

Dari pengertian yang dijelaskan di atas maka dapat saya simpulkan bahwa penelitian tindakan kelas adalah suatu cara yang dilakukan individu maupun kelompok untuk menentukan tindakan yang tetap dalam rangka pemecahan masalah dalam suatu kegiatan belajar. Model penelitian tindakan kelas yang digunakan adalah model Kemmis dan Mc 
Antonia Y.W. Wea, Maria Purnama Nduru dan Frumensius B. Dole

Penggunaan Media Audio Visual dalam Meningkatkan Pemahaman Seni Tari pada Peserta Didik Kelas V SDN Ende 5 Kabupaten Ende

PRIMA MAGISTRA: Jurnal Ilmiah Kependidikan Nomor 1, Volume 1, April 2020, hal 77-84

Taggart. Pada hakekatnya berupa perangkatperangkat atau untaian-untaian dengan satu perangkat terdiri dari empat komponen, yaitu: perencanaan (Planning), tindakan (Acting), pengamatan (Obseving), dan refleksi (reflecting). Keempat komponen dipandang sebagai salah satu siklus ( Kusumah dan Dwitagama ,2012:21). Penelitian tindakan kelas ini dilaksanakan di SDN Ende 5 jalan Dwi Sartika Kelurahan Ppotulando Kecamatan Ende Tengah Kabupaten Ende. Pengumpulan data yang dilakukan pada penelitian ini meliputi beberapa teknik yaitu: wawancara, observasi, dokumentasi, dan tes.

Dalam analisis data digunakan beberapa teknik yaitu analisis data hasil observasi, dan analisis data tes.

a) Analisis data hasil observasi

Untuk mengetahui hasil observasi menggunakan teknik persentase dengan analisis keaktifan peserta didik dalam proses belajar mengajar dengan rumus:

$\mathrm{P}=\frac{\text { jumlah skor }}{\text { jumlah skor maksimum }} \times 100 \%$

Deskripsi penilaian berpijak pada pendapat Borich, (dalam Trianto,2011), yakni:

$75-100=$ baik

$54-64=$ kurang

$65-74=$ sedang

$<50=$ buruk

b) Analisis data tes

Data tes dianalisis dengan menggunakan acuan tingkat pemahaman peserta didik berupa analisis tes dilakukan secara deskriptif analisis dan dihitung menggunakan rumus:

$$
\text { Nilai }=\frac{\text { skoryangdiperoleh }}{\text { skormaksimal }} \times 100
$$

\section{HASIL DAN PEMBAHASAN}

\section{A. Hasil penelitian}

\section{Data awal}

Untuk mengetahui tingkat kemampuan siswa dilakukan tindakan awal. Tindakan awal dilaksanakan pada tanggal 17 mei 2019 dengan jumlah siswa 28 orang. Yang mencapai nilai KKM hanya 11 orang dan 17 orang lainnya tidak tuntas. KKM yang ditetapkan SDN Ende 5 khususnya dalam mata pelajaran seni tari (SBDP) adalah 75 maka dengan ini perlu diadakan tindakan.

Adapun data pemahaman siswa kelas V sebelum tindakan, dapat dilihat pada tabel 1 di bawah ini.

Tabel 1.

Data Hasil Tes Awal Siswa

\begin{tabular}{llcc}
\hline \multirow{2}{*}{ No } & Keterangan & Hasil & Persentase \\
\hline 1 & Tuntas & 11 orang & $39,28 \%$ \\
\hline 2 & Tidak tuntas & 17 orang & $60,71 \%$ \\
\hline 3 & Rata-rata & \multicolumn{2}{c}{74,42} \\
\hline
\end{tabular}

Dari data di atas dapat diketahui bahwa jumlah siswa yang telah tuntas hanya sebanyak 11 orang atau $39,28 \%$ dan yang belum tuntas sebanyak 17 orang atau $60,71 \%$ dengan rata-rata 74,42. Dilihat dari tabel data hasil tes awal siswa belum memuaskan, peneliti melanjutkan kesiklus selanjutnya.

\section{Pelaksanaan siklus I}

Penelitian ini dilakukan di kelas V SDN Ende 5 tahun pelajaran 2018/2019 dengan jumlah siswa sebanyak 28 orang. Penelitian dilaksanakan pada bulan mei 2019 yang terdiri dari dua siklus. Setiap siklus dilaksanakan dengan alokasi waktu 2 x 35 menit dengan materi pola lantai tari kreasi daerah. Setiap kegiatan pembelajaran dilaksanakan dengan menggunakan media audio visual.

\section{a. Proses Tindakan Siklus I}

Pada siklus pertama dilaksanakan 1 kali pertemuan yang berlangsung pada tanggal 17 Mei 2019. Kegiatan pembelajaran disesuaikan dengan media audio visual dimulai dengan alur atau tahapan perencanaan, pelaksanaan atau tindakan, observasi dan refleksi disajikan dalam satu siklus sebagai berikut:

\section{1) Perencanaan}

Perencanaan dalam siklus I adalah sebagai berikut; menyusun RPP dengan materi tentang pola lantai tari kreasi daerah dengan menggunakan media audio visual, mempersiapkan sumber dan media pembelajaran berupa alat peraga, Menyiapkan soal evaluasi, Menyiapkan lembar observasi 
Antonia Y.W. Wea, Maria Purnama Nduru dan Frumensius B. Dole

Penggunaan Media Audio Visual dalam Meningkatkan Pemahaman Seni Tari pada Peserta Didik Kelas V SDN Ende 5 Kabupaten Ende

PRIMA MAGISTRA: Jurnal Ilmiah Kependidikan Nomor 1, Volume 1, April 2020, hal 77-84

untuk mengamati aktivitas guru dan siswa dalam proses pembelajaran.

\section{2) Pelaksanaan}

Kegiatan awal dalam siklus I adalah sebagai berikut; Guru memberikan salam dan mengajak semua siswa berdo'a menurut agama dan keyakinan masing-masing. Religius, Guru mengecek kesiapan diri dengan mengisi lembar kehadiran dan memeriksa kerapihan pakaian, posisi dan tempat duduk disesuaikan dengan kegiatan pembelajaran, Guru menjelaskan kegiatan yang akan dilakukan dan tujuan kegiatan belajar, Kegiatan inti Pada kegiatan inti yang dilakukan guru adalah; Pada awal pembelajaran, guru mengondisikan siswa secara klasikal dengan mengajak siswa untuk Memperhatikan video, Kemudian, guru mengajukan pertanyaan-pertanyan berikut, Apa nama tarian yang ada dalam video, Apa tarian daerah yang pernah siswa pelajari. Guru memberi kesempatan kepada siswa yang ingin menjawab pertanyaan tersebut dengan mengangkat tangan, Siswa menjawab pertanyaan yang diajukan oleh guru sesuai pengetahuannya, Guru memberikan pertanyaan pancingan agar siswa mengingat kembali tentang pola lantai tarian, misalnya, Apa saja pola lantai yang pernah dipelajari. Guru memberikan kesempatan kepada siswa untuk menjawab pertanyaan tersebut dengan cara mengangkat tangan, Guru juga memberikan kesempatan kepada siswa lain untuk menanggapi jawaban temannya, Guru mengapresiasi dan mengonfirmasi jawaban siswa, bahwa terdapat empat pola lantai yang telah dipelajari, yaitu pola lantai vertikal, horisontal, diagonal, dan garis melengkung.

Selanjutnya, guru meminta siswa memperhatikan gambar tari yang ada di buku siswa, Guru meminta siswa mengamati pola lantai pada tarian tersebut, Guru mengajukan pertanyaan, "Bagaimana bentuk pola lantai pada keempat gerak tari pada gambar?" Siswa diminta menuliskan jawabannya pada selembar kertas, Setelah selesai, siswa diminta menyampaikan jawabannya di depan teman sekelas. Guru memberikan kesempatan kepada siswa lain untuk menyampaikan jawabannya jika jawaban berbeda, Guru mengapresiasi dan mengonfirmasi jawaban semua siswa, Guru menjelaskan bahwa terdapat empat gerak tari yang diperlihatkan pada gambar. Pada gerak 1 menggunakan pola lantai vertikal. Pada gerak 2 menggunakan pola lantai diagonal. Pada gerak 3 menggunakan pola lantai garis melengkung. Pada gerak 4 menggunakan pola lantai horizontal.Perhatikan video yang disiapkan guru, Selanjutnya, guru meminta siswa membentuk kelompok terdiri atas lima anak, Setiap kelompok diminta berlatih memeragakan tarian tersebut, Kemudian, setiap kelompok diminta memeragakan hasil berlatih menari di depan kelompok lain, Guru megajarkan siswa untuk menghargai penampilan teman, misalnya dengan bertepuk tangan atau memberikan pujian, Siswa telah memahami pola lantai vertikal, horizontal, diagonal, dan garis melengkung, Guru meminta siswa memperhatikan video yang disiapkan guru, Selanjutnya, guru meminta siswa membuat variasi gerakan tangan, kaki, dan kepala dengan jenis pola lantai tarian sesuai dengan video yang disiapkan guru Guru memberikan waktu kepada siswa untuk berlatih.

\section{Observasi}

Setelah melakukan proses pembelajaran, penelitian dan observer mengadakan evaluasi terhadap pemahaman peserta didik selama proses pembelajaran. Keterlibatan peserta didik juga di amati selama berlangsungnya proses pembelajaran baik pada kegiatan awal, inti dan akhir. Maka pada siklus I kriteria keaktifan guru pada mata pelajaran seni tari dengan menggunakan media audio visual adalah baik dengan taraf keberhasilan $62,66 \%$. Maka pada siklus I kriteriaa keaktifan peserta didik adalah masih kurang.

\section{aktivitas guru siklu}

$$
62,66 \%
$$

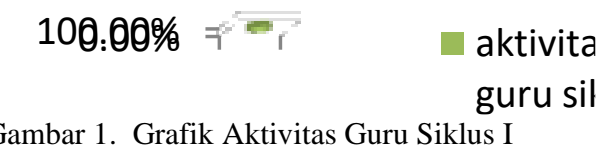


Antonia Y.W. Wea, Maria Purnama Nduru dan Frumensius B. Dole

Penggunaan Media Audio Visual dalam Meningkatkan Pemahaman Seni Tari pada Peserta Didik Kelas V SDN Ende 5 Kabupaten Ende

PRIMA MAGISTRA: Jurnal Ilmiah Kependidikan Nomor 1, Volume 1, April 2020, hal 77-84

Ada 15 aspek yang diamati dalam proses pembelajaran yang berkaitan dengan aktivitas belajar peserta didik yang perlu diperhatikan antara lain. Berdasarkan deskripsi hasil obsevasi peserta didik pada pelaksanaan silklus I keberhasilan tindakan baru memcapai 61,33\%. Maka pada siklus I kriteria keaktifan peserta didik pada pembelajaran seni tari (SBDP) dengan media audio visual adalah kurang.

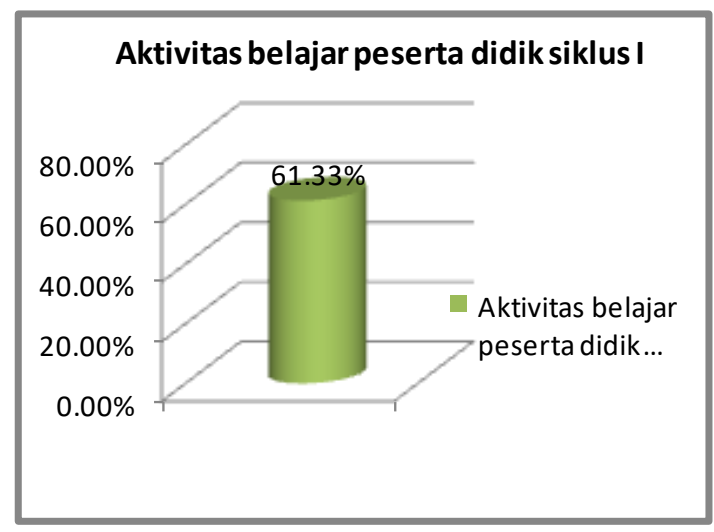

Gambar 2. Aktivitas Belajar Peserta Didik Siklus I

Untuk mengetahaui pemahaman peserta didik diperoleh melalui tes, dimana peserta didik diberikan kesempatan untuk mengerjakan soal yang diberikan guru. Untuk lebih jelas data tes dengan menggunakan media audio visual pada siklus I dapat dilihat pada tabel.

Tabel 2.

Data Hasil Tes Peserta Didik Siklus 1

\begin{tabular}{cccc}
\hline No & Keterangan & Jumlah & Persentase \\
\hline 1 & Tuntas & 14 & 50 \\
2 & Tidak tuntas & 14 & 50 \\
Rata-rata & \multicolumn{2}{c}{72,53} \\
\hline
\end{tabular}

Hasil pemahaman pada siklus I, belum mencapai ketuntasan minimum yang telah ditentukan oleh sekolah yaitu, 75. Dari 28 orang peserta didik hanya 14 orang yang memperoleh nilai diatas rata- rata yaitu $50 \%$, sedangkan yang lainnya memperoleh nilai masi di bawah rata-rata, yakni 50\%. Oleh kerna itu hasil pemahaman peserta didik siklus I dikategorikan kurang.Berdasarkan fakta di atas mengenai hasil pemahaman peserta didik rendah pada siklus I maka, peneliti dan obsever bersepakat untuk melakukan kembali pembelajaran untuk memperbaiki hasil pemahaman peserta didik pada siklus II.

\section{3) Refleksi}

Karena presentase belum mencapai target $70 \%$ maka penelitian merefleksikanPada tahap ini, penelitian mengkaji, mengevaluasi hasil tindakan yang sudah dilaksanakan. Dari hasil yang diperoleh ternyata belum semua siswa dapat memahami materi pola lantai tari kreasi daerah. Untuk memperoleh peningkatan hasil pemahaman yang maksimal, penelitian merencanakan tindakan pertemuan siklus II dan masih menggunakan media pembelajaran audio visual.

\section{b. Proses Tindakan Siklus II}

Pada siklus II dilaksanakan 1 kali pertemuan pada tanggal 20 Mei 2019. Kegiatan pembelajaran disesuaikan dengan media audio visual dimulai dengan alur perencanaan, pelaksanaan atau tindakan, observasi dan refleksi.

\section{1) Perencanaan}

Hal-hal yang harus disiapkan dalam tahap perencanaan sebagai berikut: Menyusun RPP dengan materi tentang pola lantai tari kreasi daerah dengan menggunakan media audio visual, Mempersiapkan sumber dan media pembelajaran berupa alat peraga, Menyiapkan soal evaluasi, Menyiapkan lembar observasi untuk mengamati aktivitas guru dan siswa dalam proses pembelajaran.

\section{2) Pelaksaanan}

Kegiatan awal: Guru memberikan salam dan mengajak semua siswa berdo'a menurut agama dan keyakinan masing-masing. Religius, Guru mengecek kesiapan diri dengan mengisi lembar kehadiran dan memeriksa kerapihan pakaian, posisi dan tempat duduk disesuaikan dengan kegiatan pembelajaran, Guru menjelaskan kegiatan yang akan dilakukan dan tujuan kegiatan belajar, Kegiatan inti Pada kegiatan inti yang dilakukan guru adalah: Pada awal pembelajaran, guru mengondisikan siswa secara klasikal dengan mengajak siswa untuk Memperhatikan video, Kemudian, guru mengajukan pertanyaan-pertanyan berikut, Apa nama tarian yang ada dalam video? Apa 
tarian daerah yang pernah kamu pelajari? Guru memberi kesempatan kepada siswa yang ingin menjawab pertanyaan tersebut dengan mengangkat tangan, Siswa menjawab pertanyaan yang diajukan oleh guru sesuai pengetahuannya, Guru memberikan pertanyaan pancingan agar siswa mengingat kembali tentang pola lantai tarian, misalnya, "Apa saja pola lantai yang pernah kalian pelajari?" Guru memberikan kesempatan kepada siswa untuk menjawab pertanyaan tersebut dengan cara mengangkat tangan, Guru juga memberikan kesempatan kepada siswa lain untuk menanggapi jawaban temannya, Guru mengapresiasi dan mengonfirmasi jawaban siswa, bahwa terdapat empat pola lantai yang telah dipelajari, yaitu pola lantai vertikal, horisontal, diagonal, dan garis melengkung, Selanjutnya, guru meminta

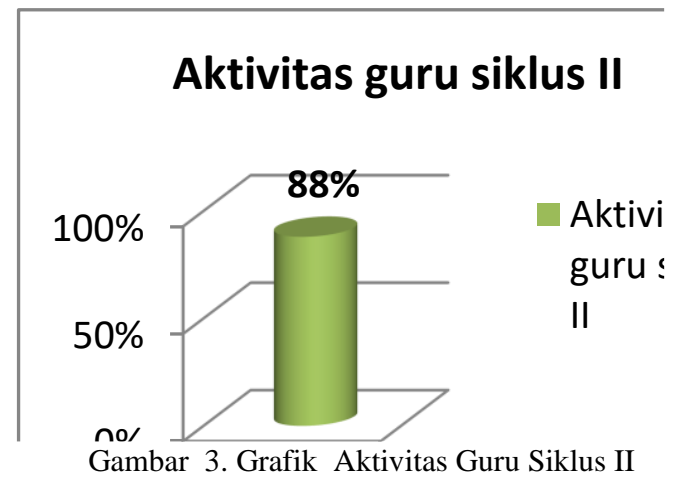

Ada 15 aspek yang diamati dalam proses pembelajaran yang berkaitan dengan aktivitas belajar peserta didik. Berdasarkan deskripsi hasil obsevasi peserta didik pada pelaksanaan silklus II keberhasilan tindakan meningkat memcapai 90,66\%. Maka pada siklus II kriteria keaktifan peserta didik pada pembelajaran seni tari (SBDP) dengan media audio visual adalah sangat baik.Secara visual hasil pengamatan aktivitas belajar peserta didik dapat dilihat pada grafik di bawah ini.

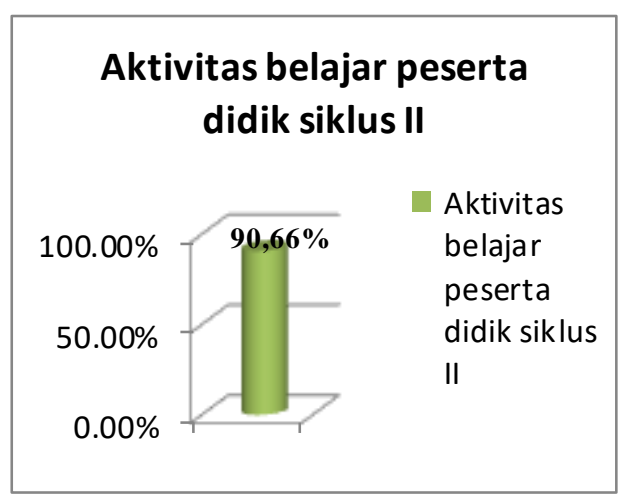

Gambar 4. Grafik Aktivitas Belajar Peserta Didik Siklus II

Untuk mengetahaui pemahaman peserta didik diperoleh melalui tes, dimana peserta didik diberikan kesempatan untuk mengerjakan soal yang diberikan guru. Untuk lebih jelas data tes dengan menggunakan media audio visual pada siklus I dapat dilihat pada tabel di bawah ini.

Tabel 3

Data Hasil Tes Peserta Didik Siklus II

\begin{tabular}{clcc}
\hline No & Keterangan & Jumlah & Persentase \\
\hline 1 & Tuntas & 23 & 82,14 \\
2 & Tidak tuntas & 5 & 17,85 \\
3 & Rata-rata & \multicolumn{2}{c}{78,67}
\end{tabular}

Hasil pemahaman pada siklus II, di atas memperoleh jumlah siswa yang telah tuntas sebanyak 23 orang atau sebesar $82,14 \%$ dengan kriteria sangat baik dan yang belum tuntus sebanyak 5 orang atau sebesar $17,85 \%$. Sedangkan nilai tertinggi adalah 94 dan nilai terendah adalah 44 serta rata-rata perolehan nilai untuk siklus II adalah 78,67\%. Ini menunjukkan rata-rata hasil tes pehaman peserta didik pada siklus II berkriteria baik.

\section{3) Refleksi}

Berdasarkan hasil observasi menunjukkan bahwa skor tingkat keberhasilan siswa mendapat kriteria baik yaitu 23 siswa sudah mencapai KKM yang telah ditentukan. Indikator pengamtan siswa hampir semua mendapat kategori sangat baik dengan rentangan nilai 4-5 yaitu keseriusan menerima pelajaran, keseriusan menampilkan tarian dan bertanggung jawaban dalam mengerjakan soal evaluasi. 
Antonia Y.W. Wea, Maria Purnama Nduru dan Frumensius B. Dole

Penggunaan Media Audio Visual dalam Meningkatkan Pemahaman Seni Tari pada Peserta Didik Kelas V SDN Ende 5 Kabupaten Ende

PRIMA MAGISTRA: Jurnal Ilmiah Kependidikan Nomor 1, Volume 1, April 2020, hal 77-84

\section{Pembahasan Hasil Penelitian}

\section{1).Penggunaan Media Audio Visual dalam Meningkatkan Pemahaman Seni Tari pada Peserta Didik}

Penggunaan media audio visual pada umumnya adalah media yang tergabung dalam audio dan visual artinya antara suara (pendengaran) dan penglihatan yang dibentuk atau dirangkai guna mempermudah dalam melakukan pengelolaan informasi. Dalam proses belajar mengajar media sangat diperlukan, sama halnya dengan pendapat Azhar Arsyad (2013:91) mengatakan bahwa fungsi utama media pembelajaran adalah sebagai alat bantu mengajar yakni yang memberikan pengelaman visual pada anak dalam rangka mendorong motivasi belajar dan mempengaruhi kondisi lingkungan belajar yang di tata dan ciptakan oleh guru". Penggunaan audio visual pada siklus I belum menunjukkan hasil yang sangat memuaskan, hal ini disebabkan karena guru belum efektif dalam memaparkan video dan melakukan gerak tari Ule Lela Nggewa sehingga siswa kurang memahami pola lantai tari kreasi daerah. Adapun kekurangan audio visual yaitu memungkinkan peserta didik lalai, kehilangan perhatian,dan membuat peserta didik pasif sehingga guru perlu melakukan tindakan selajutnya pada siklus II. Penggunaan audio visual pada siklus II terjadi peningkatan karena guru memaparkan video dengan baik dilengkapi dengan contoh gerak tari Ule Lela Nggewa dari guru sendiri sebagai mediatornya.

\section{2) Pemahaman Seni Tari Setelah Menggunakan Media Audio Visual}

Berdasarkan penelitian yang dilakukan di SDN Ende 5 pada mata pelajaran seni tari (SBdP) diketahui bahwa setelah diterapkan media audio visual pemahaman peserta didik mengalami peningkatan, yang di tinjau dari proses data awal, siklus I, siklus II.
Tabel 4. Data Rata-Rata Ketuntasan Pemahaman Siswa Tiap Siklus

\begin{tabular}{|c|c|c|c|c|c|c|}
\hline \multirow{2}{*}{ Siklus } & \multirow{2}{*}{$\begin{array}{c}\text { Jml } \\
\text { Siswa }\end{array}$} & \multirow{2}{*}{ Ratararta } & \multicolumn{2}{|c|}{ Siswayangtuntas } & \multicolumn{2}{|c|}{$\begin{array}{l}\text { Siswayangtidak } \\
\text { tuntas }\end{array}$} \\
\hline & & & $\mathrm{Jml}$ & $\%$ & Jml & $\%$ \\
\hline $\begin{array}{l}\text { Data } \\
\text { awal }\end{array}$ & 28 & 74,42 & 11 & 39,29 & 17 & 60,71 \\
\hline SikusI & 28 & 72,53 & 14 & 50 & 14 & 50 \\
\hline SiktusII & 28 & 78,67 & 23 & 82,14 & 5 & 17,85 \\
\hline
\end{tabular}

Berdasarkan nilai rata-rata yang diperoleh peserta didik pada tes siklus I dan II menunjukan ada peningkatan pemahaman peserta didik pada materi pola lantai kreasi daerah .untuk lebih jelas dapat dilihat pada grafik peningkatan pemahaman peserta didik di bawah ini:

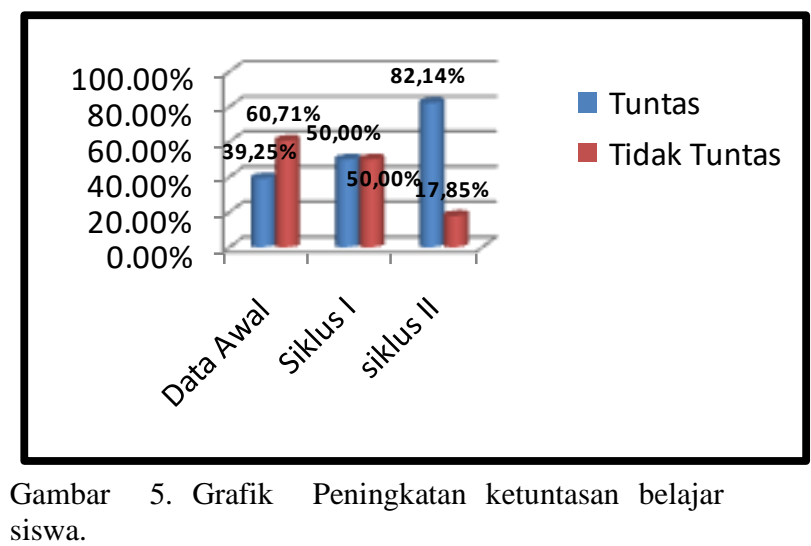
siswa.

Berdasarkan grafik di atas hasil yang dicapai dapat dinyatakan bahwa peserta didik telah berhasil melalui media audio visual yang diterapkan. Hal ini dapat dilihat bahwa pemahaman peserta didik sudah sesuai dengan apa yang diharapkan karena dalam proses melalui media pembelajaran audio visual, peserta didik diberikan kesempatan untuk mencari tahu sendiri dalam kelompok yang kemampuan berbeda.

Analisis hasil observasi mulai dari siklus I dan II, dapat kita ketahui bahwa seluruh peserta didik terlihat aktif selama proses KBM. Dengan perubahan pningkatan nilai rata-rata dan ketuntasan belajar dari setiap siklus sudah mencapai target yang diinginkan dan penelitian sudah dikatakan berhasil dalam meningkatan pemahaman 
Antonia Y.W. Wea, Maria Purnama Nduru dan Frumensius B. Dole

Penggunaan Media Audio Visual dalam Meningkatkan Pemahaman Seni Tari pada Peserta Didik Kelas V SDN Ende 5 Kabupaten Ende

PRIMA MAGISTRA: Jurnal Ilmiah Kependidikan Nomor 1, Volume 1, April 2020, hal 77-84

peserta didik mata pelajaran seni tari (SBdP) materi pola lantai kreasi daerah.

\section{SIMPULAN DAN SARAN}

Penggunaan audio visual pada siklus I belum menunjukkan hasil yang sangat memuaskan, hal ini disebabkan karena guru belum efektif dalam memaparkan video dan melakukan gerak tari Ule Lela Nggewa sehingga siswa kurang memahami pola lantai tari kreasi daerah. Adapun kekurangan audio visual yaitu memungkinkan peserta didik lalai, kehilangan perhatian,dan membuat peserta didik pasif sehingga guru perlu melakukan tindakan selajutnya pada siklus II. Penggunaan audio visual pada siklus II terjadi peningkatan karena guru memaparkan video dengan baik dilengkapi dengan contoh gerak tari Ule Lela Nggewa dari guru sendiri sebagai mediatornya.

Pada siklus I ketuntasan pemahaman peserta didik hanya $50 \%$ atau 14 orang peserta didik yang tuntas, sedangkan $50 \%$ atau 14 orang lainnya tidak tuntas dalam pembelajaran. Sedangkan pada siklus II persentase ketuntasan meningkat menjadi $82,14 \%$ atau dari 23 orang peserta didik dan 5 orang lainnya tidak mencapai ketuntasan atau $17,53 \%$. Begitu pula dengan pemahaman siswa dari $72,53 \%$ pada siklus I meningkat menjadi $78,67 \%$.

\section{DAFTAR PUSTAKA}

Azhar, Arsyad . 2013. Media pembelajaran. Jakarta:Pt Raja Grafindo Persada

Kusumah, Wijaya dan Dwitagama, Dedi. 2012. Mengenal Penelitian Tindakan Kelas.Jakarta barat:PT Indeks

Mulyasa. 2012. Praktik Penelitian Tindakan Kelas. Bandung: PT Rosdakarya

Musfiqon. 2012. Metedologi Penelitian Pendidikan. Jakarta:PT Prestasi Pustakaraya

Ningrum, Epon. 2014. Penelitian Tindakan Kelas. Yogyakarta: Ombak

Triyono. 2013. Metodologi Penelitian Pendidikan.Yogyakarta:Ombak

Trianto. 2011. Panduan lengkap penelitian tindakan kelas. Surabaya :Bumi Aksara
Umar, Tirtarahardja dan La,Sulo. 2010. Pengantar Pendidikan. Jakarta: PT Rineke Cipta

Wirhadit, Kuswaya dan Wardhani, Igak. 2012. Penelitian Tindakan Kelas. Tangerang Selatan: Universitas Terbuka 